[DOI: 10.24214/jecet.A.9.3.50223.]

Jaurnal of Environmental Science, Computer Science and Engineering \& Technology

An International Peer Review E-3 Journal of Sciences and Technology

Available online at www.jecet.org

Section A: Environmental Science

Research Article

\title{
Effective Water Resources Management for Communities in the Chi River Basin in Thailand
}

\author{
${ }^{1}$ Prasit Prakongsri \&2Toansakul Tony Santiboon \\ ${ }^{1}$ Department of Agricultural Extension, Faculty of Agriculture, Khon Kaen University, Khon Kaen, \\ Thailand \\ ${ }^{2}$ Science, Mathematics, and Technology Education Center, Curtin University of Technology, WA, \\ Australia
}

Received: 09June 2020; Revised:16 July 2020; Accepted: 27 July 2020

\begin{abstract}
Using the participatory action research methodology (IPAR) method, the input, and knowledge of different stakeholder groups is an ongoing process to establish the best water user practices to allocate limited resources. Ongoing studies are being held for barrier and flood prevention solutions, integration of competing water user sectors, and evaluation of customary practices and rules. The establishments of updated regulations are necessary for future enforcement so that water allocation and management is effective and fair for all users. This article addresses effective and fair water resource management regulation (EFWRMR) for water user organizations in the Chi River Basin in Thailand, The development of water resource management regulations of water users organizations are based surveys, analysis, and development of regulations through methodologies and research from organizations and users which broadly include water users, households, community leaders, government agencies, NGOs, other institutions and organizations characterized as Integrated Participatory Action Research ("IPAR"). Using the IPAR methodology, the study compiled information to form a comprehensive survey. Topics included problems floods and droughts, and water and solutions such as developing water reservoirs along the natural swamps, other storage capacities, and water management. Legal experts were consulted Legal experts were consulted on
\end{abstract}


water management, the current state of the ecological community, and draft governmental regulations.

Keywords: Integrated participatory action research methodology (IPAR), legal claims traditional rules and regulations, effectiveness and fairness, water resources for user's managementclaims

\section{INTRODUCTION}

Background of the River Basins of Thailand: The "Kingdom of Thailand", in short, "Thailand", is governed by a constitutional monarchy with a parliamentarian form of government. Thailand is divided into 76 provinces, administratively; the country is divided into four regions: the North, the Northeast or the Khorat Plateau, the Central Plain or the Chao Phraya Basin, and the South or the southern Isthmus. The Northeast consists of the Khorat Plateau. It comprises several small river basins, which drain into the two principal rivers Chi and Mun, and through these rivers flow into the Mekong River. This region is the center to produce rubber and cultivation of other tropical crops ${ }^{[1]}$.

For water quality, the monitoring program showed that mitigation and development measures are needed such as the construction of wastewater treatment plants, hazardous waste treatment, agricultural waste management, industrial waste control, and management of other pollution sources ${ }^{[2]}$ (Figure 1).
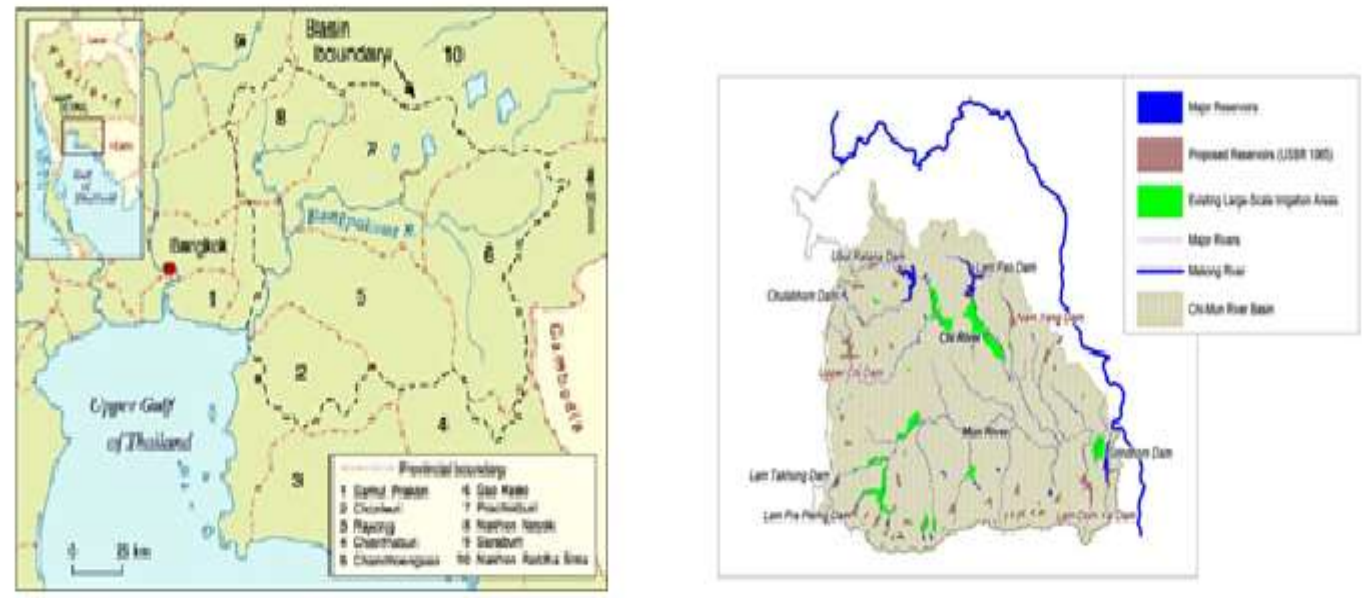

(a) The sample areas of the river basins from 25-river basins in Thailand

(b) The target indicating study in the Chi River Basin in the Northeastern Region

Source:Food and Agriculture Organization ${ }^{[1]}$

Fig. 1: shows the location of the characteristics of the 25 major river sub-basinsin Thailand

The Thai government has set up the policy on national water resources management and formulated strategies to resolve water shortages, floods, and water quality; and increasing the effectiveness of 
water resources management. Therefore, the Department of Water Resources has established the river basin organizations for all 25 river basins. Each river basin organization body comprises a river basin committee, river basin sub-committee for various fields, river basin working group at the provincial level, and river basin working group at river basin and at sub-basin levels and networks.

The established river basin bodies function to mobilize water resources management with participation from all sectors. To increase the effectiveness of water resources management, these organizations must still be strengthened in management, maintenance, rehabilitation and conservation of water resources as well as better plans both at the river basin and local levels ${ }^{[3]}$ (Figure 2).

\section{MATERIALS AND METHODS}

A review of the general condition of the Chi River Basin was to provide the information needed to build awareness, access to facts, and enhance the capacity and potential for self-development of human resources. Water users and water user organizations gave consideration to the physical, biological, economic, social, lifestyle, cultural, and community concerns pertaining to the Chi River Basin. The IPAR method was implemented.

Research Objectives: The research accomplished was to integrate a variety of interests to determine a sense of fairness for allocating water resources management for multiple users among the solutions common to all sectors is barriers and flood prevention of the Chi River Basin in Northeastern, Thailand
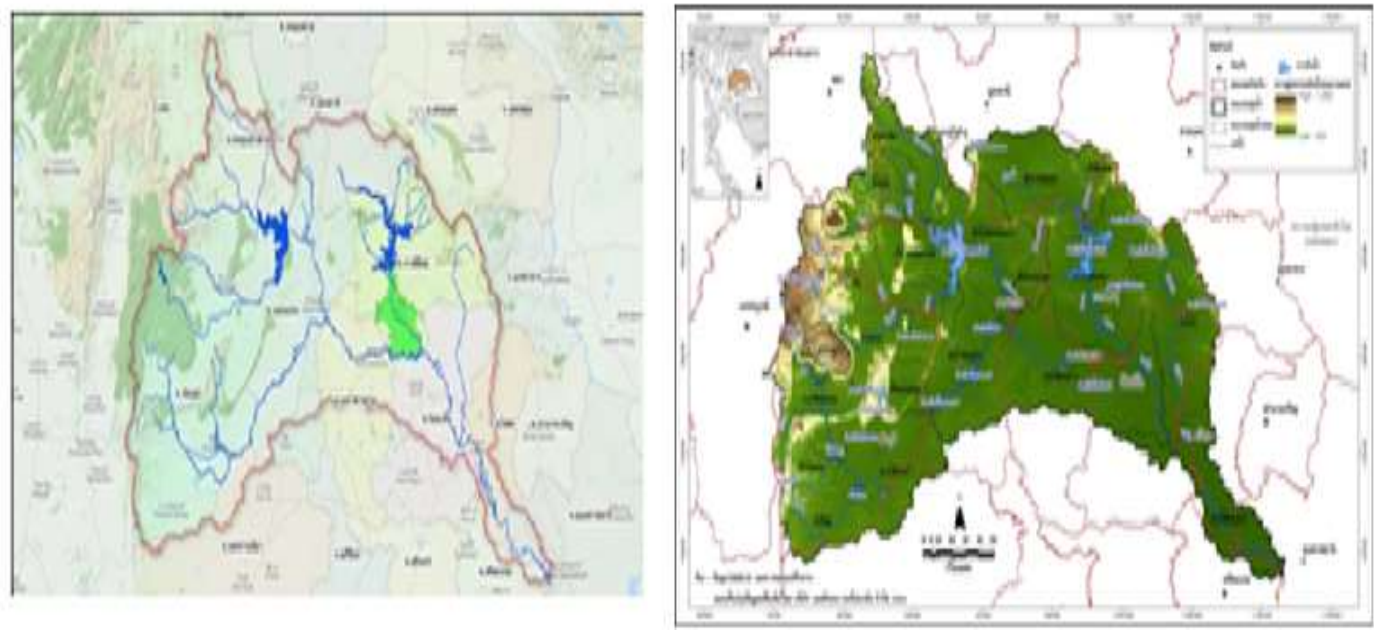

Source: Water Crisis Prevention Center ${ }^{[5]}$ )

(a) Topographic map of Chi River Basin

(b).Branches of the Chi River

Fig. 2: Shows the graphics of forestry resource in boundary and utilizing lands in the national parks of governance through the Chi River Basin

Department of Water Resources in the Chi River Basin of Thailand: The great importance to the role of the local community; encourage knowledge, understanding and participation process of people, basin organization and networks, the local administration authority, and other involved agencies in water resources management, allocation, and efficiency are integrated ${ }^{[4]}$ (Figure 2). 
The Chi River Basin is an area with a strong social resource base. Civil society networks comprise the northeastern network of philosophers and organic rice network. The network has grown rapidly over the past 15 years. The number of network members is estimated to be at least 50,000, knowledgeable about water resources and management. The total area is 4.9 million ha with a population of 6.6 million people. It is located in the tropical monsoon region. The annual rainfall varies from 1,000 $1,400 \mathrm{~mm} /$ year $^{[5]}$.

In rural areas, where about $61 \%$ of the people live. Presently, the majority of the river basin, the population is engaged in agriculture on the $60 \%$ of arable land where $41 \%$ is paddy fields, Their maiming area is a forest $(31 \%)$, urban $(2.9 \%)$, water bodies $(2.5 \%)$, and others $(3.5 \%)^{[5]}$.
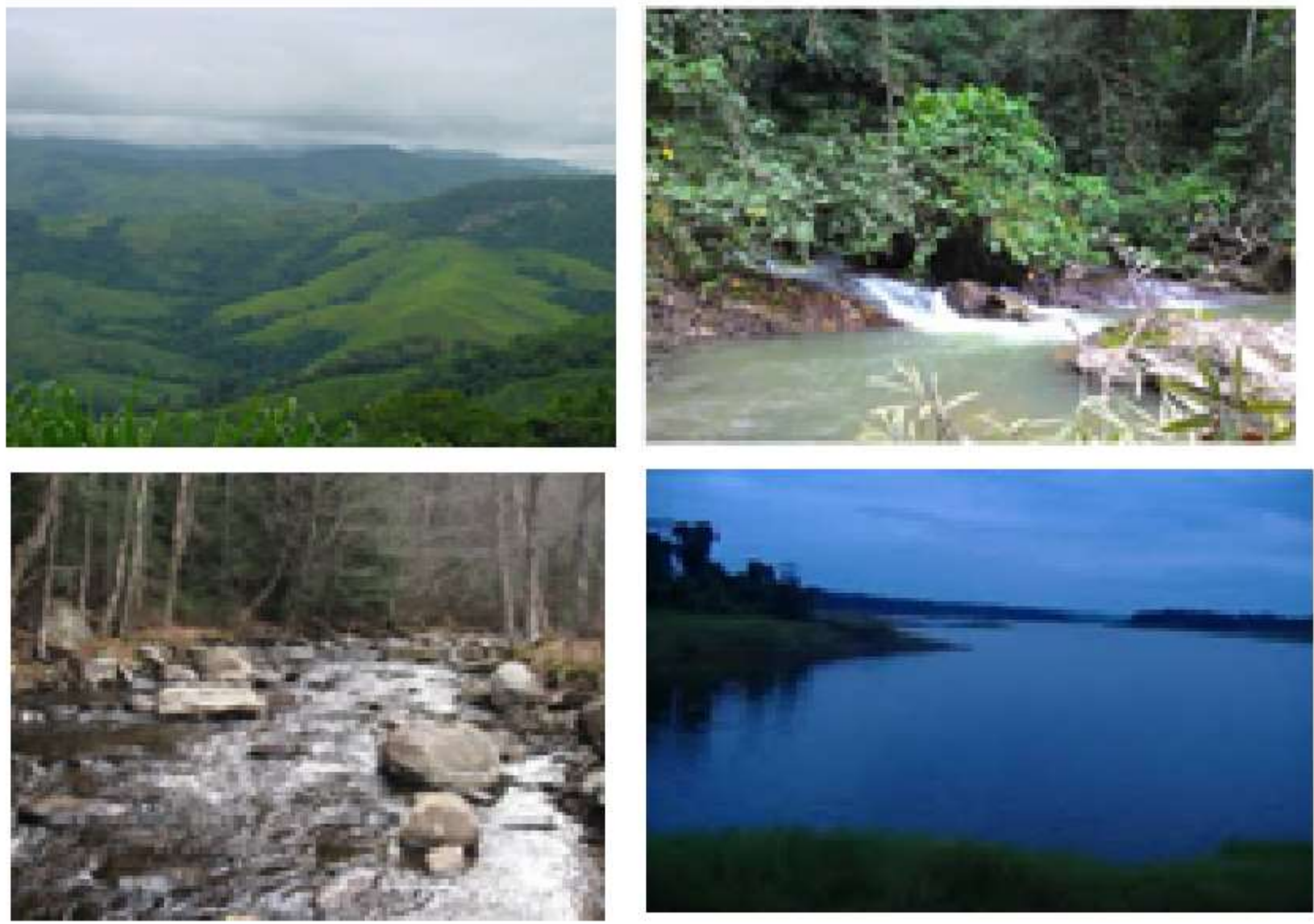

Source: Majang ${ }^{[6]}$

Fig. 3: The head water of the Chi River Basin, and the Petchbun Mountains whereas the original of the Chi River

The Chi River Basin constitutes approximately one-third of landmass and population of the Northeast region of Thailand. To contribute to a better understanding of hydrologic processes and to synthesize all available data sets (time series and GIS data) in the Chi River Basin, the application of a hydrological model is used. The Ministry of Natural Resources and Environment is responsible for the policy and overall planning of natural resources including water resources, while the Ministry of 
Agriculture and Cooperatives are mainly responsible for the implementation and operation of the infrastructure for the agricultural areas ${ }^{[7]}$ (Figure 4).
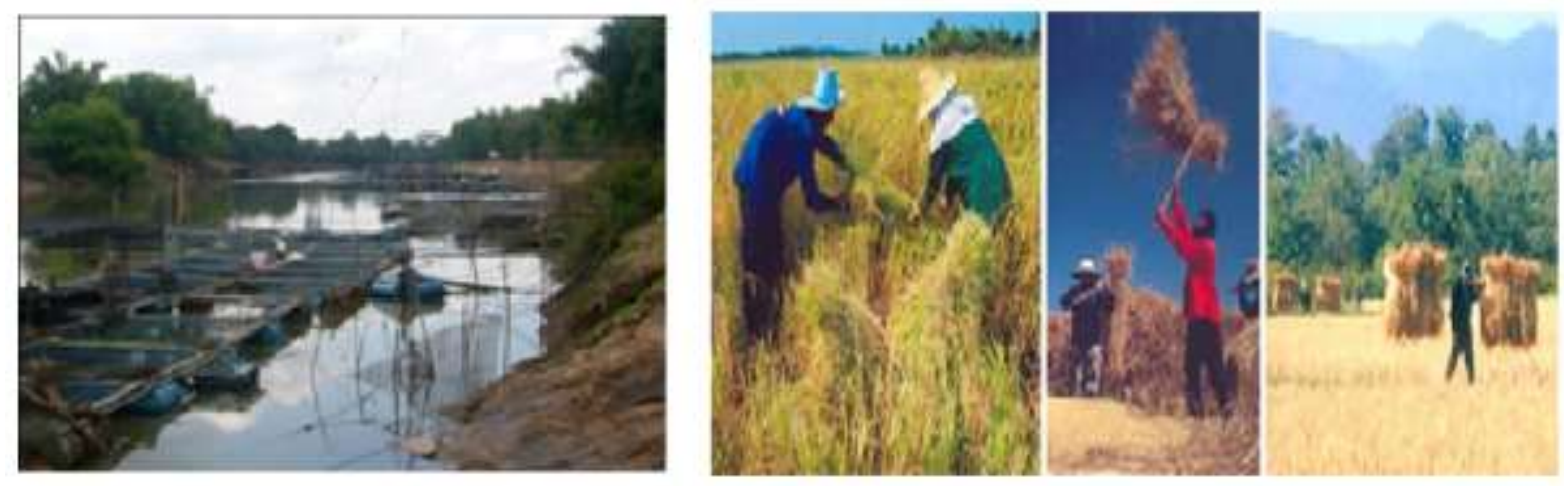

(a). Fish cage culture farm in the Chi River (b). Rice produced from rice field whereas surrounding the Chi River Basin

Source: RakThammachat.com ${ }^{[8\}}$

Fig. 4: Occupation projects' model and irrigation activity areas of the Chi River Basin

The Water User Organizations (WUOs): There are four levels of water user organization in the irrigation areas: Water User Group (WUG): the smallest groups, responsible for one tertiary irrigation canal. In 2014, there are 14,930 WUG with 358,846 farmer members. Integrating Water Users Group (IWUG) is the integration of many WUGs to cover one level up of irrigation canals. The secondary canals, there are 410 IWUGs with 234,203 farmer members. Water Users Association (WUA) is a legally recognized IWUG with 40 WUAs and 17,575 farmer members. The IWUG is not profitoriented. The Water Users Cooperative (WUC) is the cooperative form of a WUA. There are 83 WUCs with 53,158 farmer members and the WUC is business-oriented ${ }^{[9]}$.

This study was designed to enable a better understanding of water resources to be managed in a more informed and enlightened manner, resulting in healthy ecosystems. In addition, water resources need to be distributed in an equitable and sustainable fashion to allow for a multitude of different uses. Increased attention is needed in the rain-fed areas, and include upstream forest areas to create moisture to absorb the water and slow down the severity of floods in the river basins. Water resource allocation will also be affected by climate change, external economies, population changes, and new technologies ${ }^{[4]}$ (Figure 5).

This research evaluated the relevant data in order to generate guidance rules and regulations to manage limited resources. The content of regulations on water use varies by ecological, cultural, and water-related conditions. The development of water resource management regulations of water users organizations are based on the local wisdom and surveys, analysis, and existing participatory action research methodologies that integrate significant input from a wide variety of organizations, institutions, community and government leaders, NGO's, and specialists on water resources (Integrated Participatory Action Research: "IPAR"). 

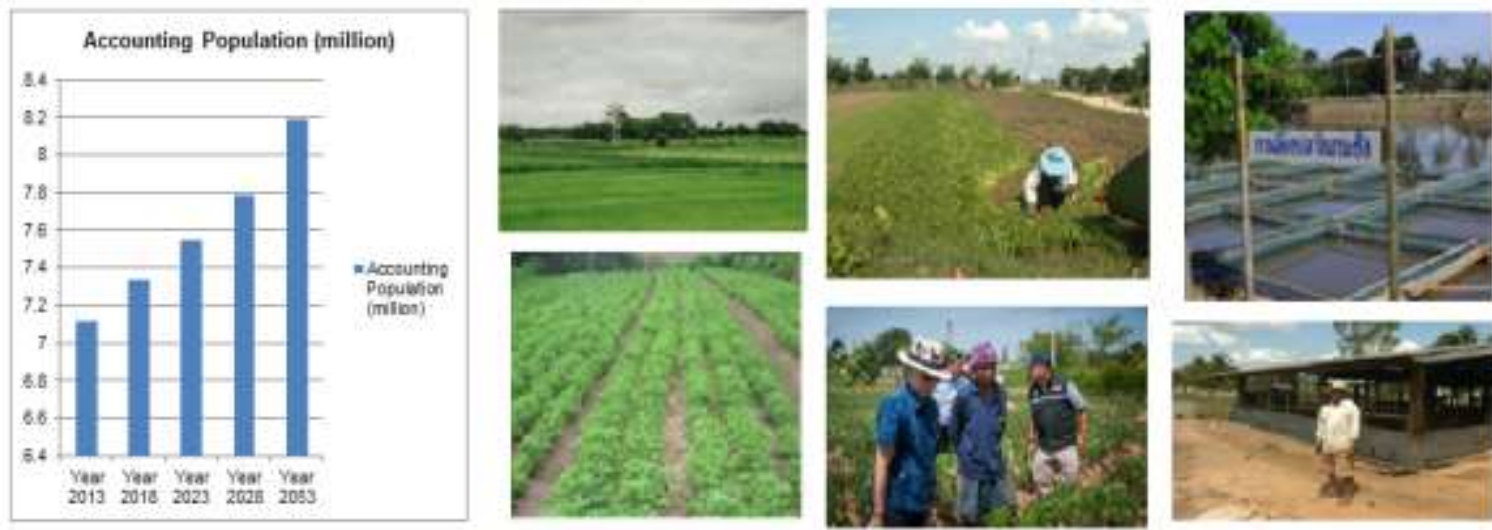

Source:(a) The World Bank Document ${ }^{[10]}$ (b) Office of Royal Development Projects Board (RDPB) ${ }^{[11]}$

(a). Population projection for the Chi River Basin (b). People's occupations at surrounding the Chi River Basin

Fig. 5: Graphic of population projection (a) and population's occupations at the Chi River Basin (b)

The IPAR practitioners make a concerted effort to integrate three basic aspects of their work: participation (life in society and democracy), action (engagement with experience and history), and research (soundness in thought and the growth of knowledge). "Action unites, organically, with research" and collective processes of self-investigation. The way each component is actually understood and the relative emphasis it receives varies nonetheless from one IPAR theory and practice to another. This means that IPAR is not a monolithic body of ideas and methods but rather a pluralistic orientation to knowledge making and social change (Figure 6).
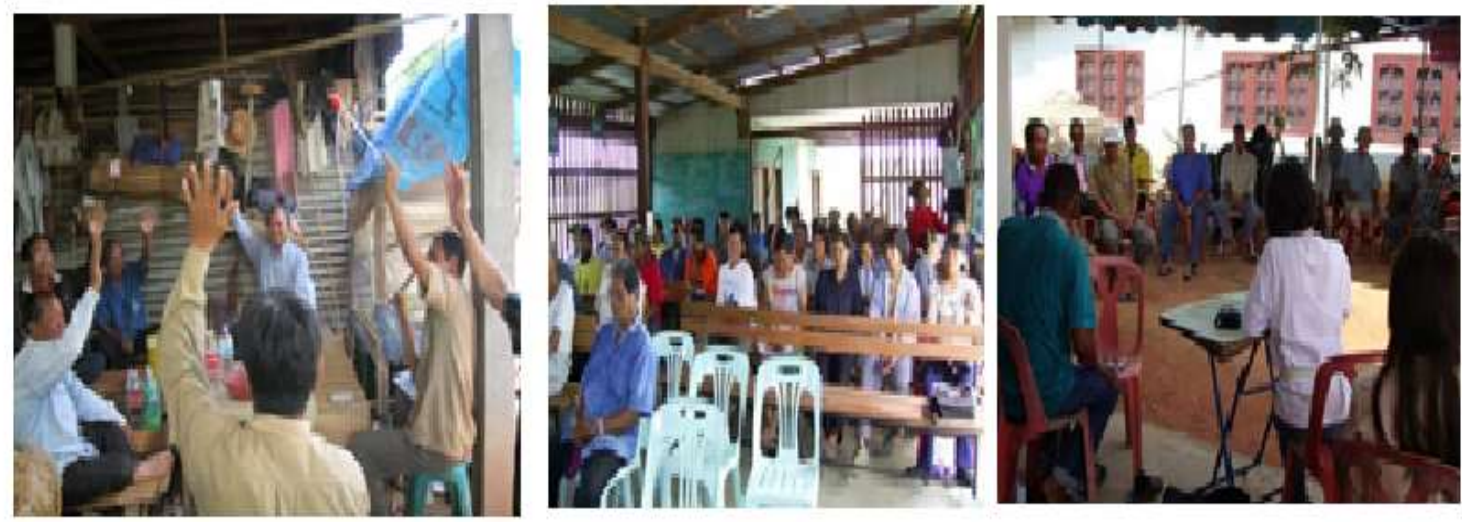

\section{Source: Research team}

Figure 6.Local wisdom and traditional water management of rural communities with the Integration

Participatory Action Research (IPAR) method are the group discussions and solving-problem concencious according the traditional and regular roles in effectiveness and fairness of the Chi River Basin with researcm team together 


\section{RESEARCH PROCEDURES}

\section{Step I: Integrated the Reviewing Content Related Research}

1. Selected the Chi River to the IPAR Research Method: Water continues to flow into the Chi river, causing floods in paddy fields and damaging rice crops that are about to produce grains ${ }^{[12]}$.

The study focused on the Chi River Basin and the Branch Dividing Streams, which include Lam Nam Pong, Lam Nam Proam, Lam Nam Pao, Lam Nam Choen, and Lam Nam Young. These streams, these are important in the water resource streams for agricultural and irrigation, areas, cropping systems. These streams are important for agricultural and irrigation, cropping systems, and personal consumption.

Location and Geographical of the Chi River: Table 1 reports the Chi River Basin is in Northeastern Thailand. There are 49,131.92 square kilometers or 30,707,453 rai. Most of them are in 14 provinces including Chaiyaphum, KhonKaen, NongBua Lam Phu, Udon Thani, Maha Sarakham, Nakhon Ratchasima, Loei, Phetchabun, Kalasin, Roi-Et, Yasothon, Ubon Ratchathani, Sisaket, and Mukdahan

Table 1:Coverage of the Chi River Basin in the Provincial Areas

\begin{tabular}{|c|c|c|c|c|c|}
\hline \multirow[t]{2}{*}{ Province } & \multirow{2}{*}{$\begin{array}{l}\text { Provincial } \\
\text { Area } \\
\left(\mathrm{Km}^{2}\right)\end{array}$} & \multicolumn{2}{|c|}{ Water Area of the Chi River } & \multirow{2}{*}{$\begin{array}{l}\text { Percentage } \\
\text { of } \\
\text { Provincial } \\
\text { Area }\end{array}$} & \multirow{2}{*}{$\begin{array}{l}\text { Percentage of } \\
\text { the Chi Water } \\
\text { Area }\end{array}$} \\
\hline & & $\mathrm{Km}^{2}$ & $\begin{array}{l}\text { Rai (1 Rai = } 0.395^{2} \\
\text { Acre) }\end{array}$ & & \\
\hline Kalasin & $6,928.45$ & $6,928.43$ & $4,320,264$ & 100.00 & 14.10 \\
\hline KhonKaen & $10,643 \cdot 33$ & $9,549.41$ & $5,968,570$ & 89.72 & 19.44 \\
\hline Chaiyaphum & $12,654.45$ & $12,489 \cdot 30$ & $7,805,763$ & 98.70 & 25.42 \\
\hline NakhonRatchasima & $20,878.92$ & 838.96 & 524,348 & 4.04 & 1.71 \\
\hline Petchabun & $12,348.59$ & 873.25 & 545,154 & 7.06 & 1.78 \\
\hline MahaSarakham & $5,635 \cdot 99$ & $2,997.47$ & $1,873,416$ & 53.18 & 6.10 \\
\hline Mukdahan & $4,123.67$ & $47 \cdot 51$ & 29,693 & 1.15 & 0.09 \\
\hline Yasothorn & $4,135 \cdot 45$ & $1,739.20$ & $1,087,002$ & 42.06 & 3.54 \\
\hline Roi-Et & $7,861.03$ & $4,685.78$ & $2,928,166$ & 59.61 & 9.54 \\
\hline Lopburi & $6,502.35$ & 2.91 & 1,818 & 0.04 & 0.01 \\
\hline Loei & $10,473 \cdot 34$ & 1.638 .31 & $1,023,944$ & 15.64 & 3.33 \\
\hline Sisaket & $8,935.85$ & 259.70 & 162,311 & 2.91 & 0.53 \\
\hline SakonNakhon & $9,586.04$ & 2.71 & 1,634 & 0.03 & 0.01 \\
\hline NongbuaLamphu & $4,090.40$ & $3,015.88$ & $1,884,926$ & 73.73 & 6.14 \\
\hline UdonThani & $11,074.79$ & $3,380.62$ & $2,112,888$ & 30.53 & 6.88 \\
\hline UbonRatchathani & $15,621.40$ & 683.29 & 427,056 & $4 \cdot 37$ & 1.39 \\
\hline Total & 151,494.05 & $49,131.22$ & $30,707,453$ & 32.43 & 100.00 \\
\hline
\end{tabular}

The watershed is located between latitudes $15^{\circ} 30^{\prime} \mathrm{N}-17^{\circ} 30^{\prime} \mathrm{N}$ and between the longitude at $101^{\circ} 30$ 'E - 104 $30^{\circ}$ ' N East. The topography of the Chi Basin is composed of high mountains. The coverage of the Chi River Basin is shown in Table $1{ }^{[13]}$ (Figure 7, and Table 1). 

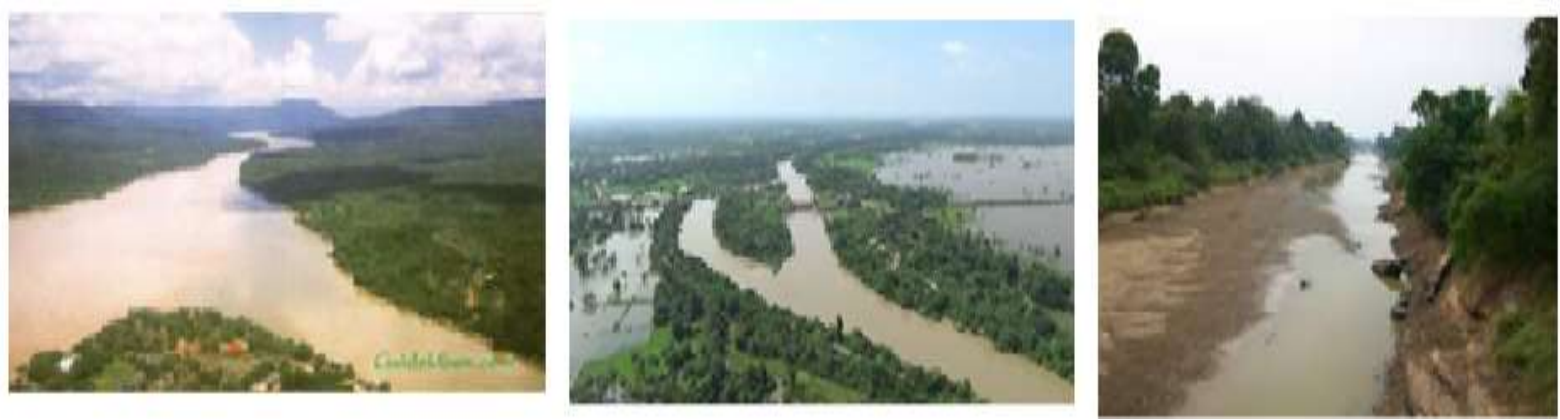

Source: GuideUbon.com ${ }^{[14]}$

The longest river of Thailand, the Chi River

\section{Water flood in the Chi River Basin}

Water Drought in the Chi River

Fig. 7: Environmental locations and situations in the different seasons

The central and lower parts of the Chi Basin include the terrain which is a shallow wave and the lowland floods impact the area of prominence rice fields. The use of water in the summer season is inadequate because of the lack of water storage. A map of 1: 50,000 scale maps are currently used by the Department of Mapping which shows the irrigation area of the Chi River Basin is divided into 20 tributaries. The Lam Nam Proam Tributary is originating from the mountains of Dong Phayayen, which the divide of the Chi River Basin and the Pasak Basin flows through Chaiyaphum province to meet the Lam Nam Choen Tributary and then flows into Ubonratana Dam reservoir ${ }^{[15]}$ (Figure 8 and Table 1).
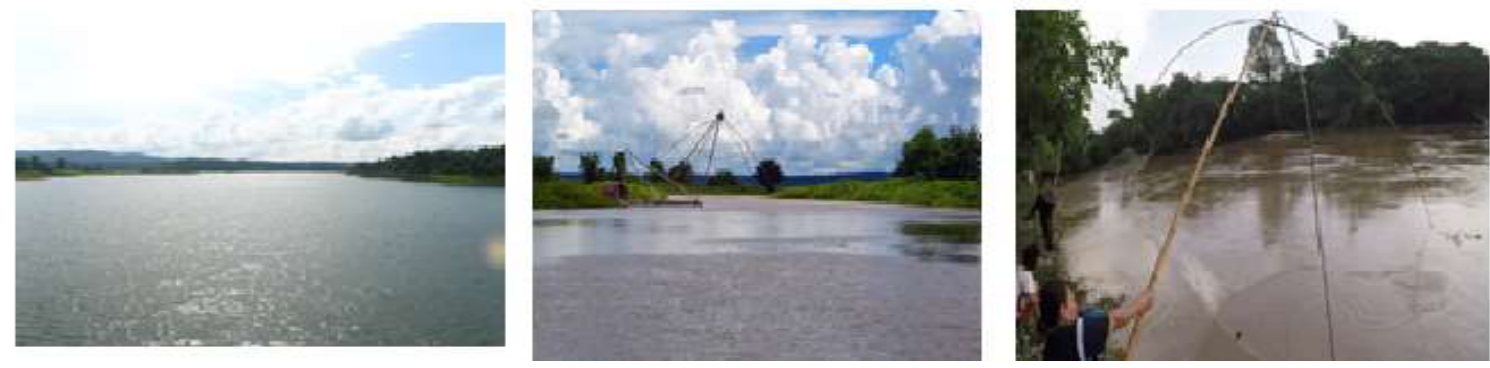

(a) Proam water stream

(b) Pao water stream

(c) Choen water stream

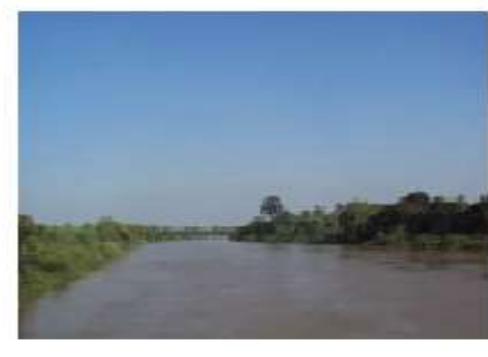

(d) Young water stream

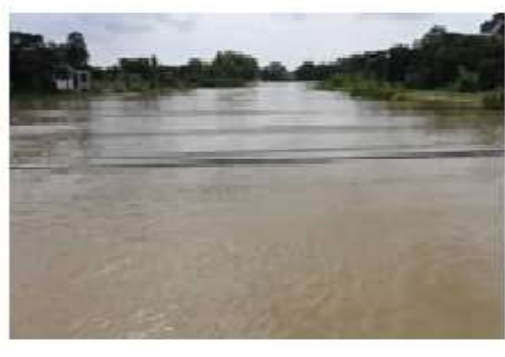

(e) Pong water steam

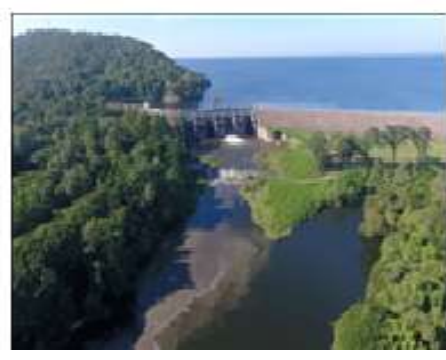

(f) Pong Water Dam (Ubol Ratana Dam)

Source: BasisChiInfo ${ }^{[16]}$

Fig. 8: Main Chi River profiles' activities of Northeastern Region, the 5-branch streams, and river's resource management with the Dams, water storage weir, drainage weir 
The Lam Nam Choen originates from the Dong Phaya Yen Mountains. Nam Phong originated from PhuKradueng Mountain, flows through Phu Kradueng and the district in Loei province to KhonKaen before converting to the Chi River at Muang District, Khon Kaen. The Pao Tributary originated from Nong Han, Kumphawapi District in Udon Thani, flows through Kalasin province, and comes with the Chi River at Ongka District. The Yong Tributary also originates from the Phu Phan mountain range.

A watershed of the Chi River Basin and the Songkram Basin flows through Kalasin and at Roi-Et with the Chi River is met before reaching Muang District, Yasothon ${ }^{[13]}$ (Figure 9, and Table 1).
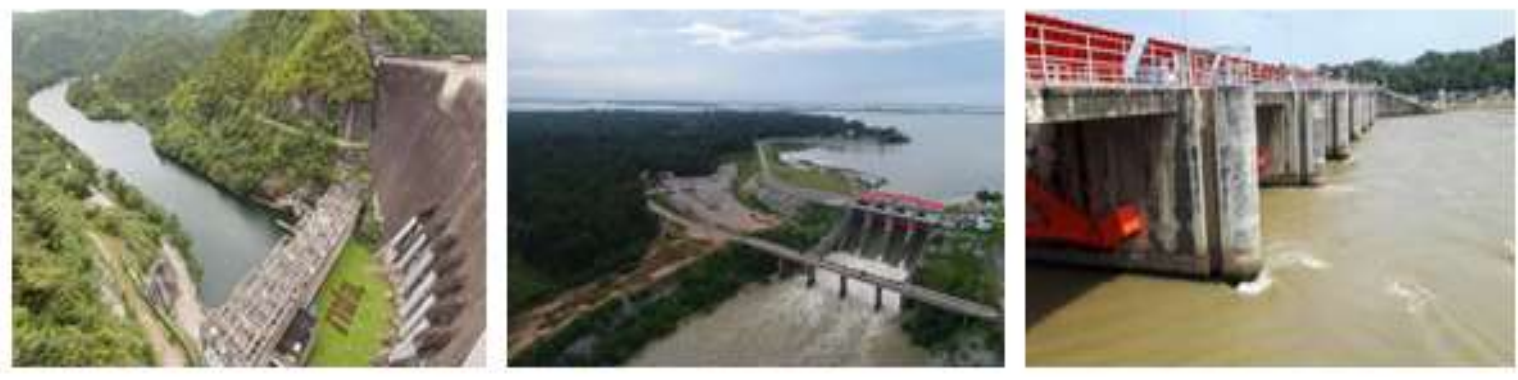
( a) Poem Water Dam
(Chulaporn Dam)

(b) Lam Pao Water Dam

(c) Chi River Dam )

Source: Electricity Generating Authority of Thailand ${ }^{16]}$

Fig. 9: The Dams, water storage weir, and drainage weir at the Brach of the Main Chi River

Forestry Resource in Boundary of Governance through the Chi River Basin: The determination of the Chi River Basin covers the territory of 14 provinces with 133 districts. There is 10,093,042 rai of national forest reserves, representing $32.87 \%$ of the watershed area. Forest status in the Chi River Basin is relatively low. There are also 11 national parks, 6 wildlife sanctuaries, 3 non-hunting zones, and 4 wetlands. They can be classified according to the type of land use in the National Forest, National Park, Information Wildlife Sanctuary Wild Hunting, and Zone Wetland (Table 2).

Table 2: Types of the Utilizing Lands in the National Parks through the Chi River Basin

\begin{tabular}{|c|c|c|c|c|c|}
\hline \multirow[t]{3}{*}{ No. } & \multirow[t]{3}{*}{ Code } & Utilizing Lands in the & \multicolumn{2}{|c|}{ Water Area of the Chi River } & \multirow{3}{*}{$\begin{array}{l}\text { Percentage of the } \\
\text { Chi River Basin } \\
\text { Area }\end{array}$} \\
\hline & & National Parks through the & $\mathrm{Km}^{2}$ & Rai & \\
\hline & & \multicolumn{3}{|l|}{ Chi River Basin } & \\
\hline 1. & A & Agriculture Zone & $1,728.40$ & $1,080,247$ & 3.52 \\
\hline 2. & $\mathrm{C}$ & Conservative Zone & $6,798.02$ & $4,248,764$ & 13.84 \\
\hline 3. & $\mathrm{E}$ & Economic Zone & 6940.33 & $4,337,703$ & 14.13 \\
\hline 4. & $\mathrm{~N}$ & Non-RED Control & $197 \cdot 36$ & 123,349 & 0.40 \\
\hline 5. & NE & Non Data & 484.77 & 302,979 & 0.99 \\
\hline & & Total & $16,148.86$ & $10,093,042$ & 32.87 \\
\hline
\end{tabular}

Source: Department of National Park, Wildlife and Plant Conservation [17] 
Branch Dividing Streams of the Main Chi River: A river is a natural flow of running water that follows a well-defined, permanent path, usually within a valley. The term stream is often used to mean any natural flow of water, including rivers. Many tributaries make up a river system ${ }^{[18]}$. There are thirteen branches, divides, or tributaries of the Main Chi River (Table 3).

Table 3. Details of the principal tributaries of the Chi River

\begin{tabular}{|c|c|c|c|c|}
\hline $\begin{array}{l}\text { Steam } \\
\text { Code }\end{array}$ & Name of Branch Stream & $\begin{array}{l}\text { Stream } \\
\text { Basin } \\
\text { Area }\left(\mathrm{Km}^{2}\right)\end{array}$ & $\begin{array}{l}\text { \%of the } \\
\text { Chi } \\
\text { River } \\
\text { Area }\end{array}$ & Covering some parts of the province \\
\hline 0402 & Upper the Chi Tributary & $2,551.31$ & 5.19 & Chaiyaphum, Petchabun, Lopburi \\
\hline 0403 & Lam Sapung & 743.27 & 1.51 & Chaiyaphum \\
\hline 0404 & Lam Krajuan & 892.79 & 1.82 & Chaiyaphum, Lopburi \\
\hline 0405 & Lam Kanchu & $1,731.29$ & 3.52 & Chaiyaphum, Nakonratchasima, Lopburi \\
\hline 0406 & The $2^{\text {nd }}$ part of Chi River & $3,784.70$ & 7.70 & KhonKaen, Chaiyaphum, Nakonratchasima \\
\hline 0407 & Sam Moh Creek & 746.89 & 1.52 & KhonKaen, Chaiyaphum \\
\hline 0408 & The $3^{\text {rd }}$ part of Chi River & $3,304.38$ & 6.73 & KhonKaen, Chaiyaphum, Mahasarakham \\
\hline 0409 & $\begin{array}{l}\text { Upper Lam Nam Pong } \\
\text { Tributary }\end{array}$ & $4,067.85$ & 8.28 & $\begin{array}{l}\text { KhonKaen, Petchabun, NongBauLamphu, } \\
\text { Loei, UdonThani }\end{array}$ \\
\hline 0410 & Lam Nam Puay Creek & 896.11 & 1.82 & Loei, NongBauLamphu \\
\hline 0411 & Lam Panieng Creek & $1,875.27$ & 3.82 & Loei, NongBauLamphu, UdonThani \\
\hline 0412 & Proam Tributary & $2,253.91$ & 4.59 & Chaiyaphum, Petchabun \\
\hline 0413 & Choen Tributary & $2,931.75$ & 5.97 & KhonKaen, Chaiyaphum, Petchabun, Loei \\
\hline 0414 & Lower Pong Tributary & $2,319.84$ & 4.72 & $\begin{array}{l}\text { KhonKaen, Mahasarakham, NongBua Lam } \\
\text { Phu, UdonThani }\end{array}$ \\
\hline 0415 & Sai Bath Creek & 676.24 & 1.38 & Kalasin, KhonKaen, Mahasarakham \\
\hline 0416 & The $4^{\text {th }}$ part of Chi River & $5,296.46$ & 10.78 & $\begin{array}{l}\text { Kalasin, KhonKaen, Mahasarakham, Roi- } \\
\text { Et }\end{array}$ \\
\hline 0417 & Upper Pao Tributary & $3,250.46$ & 6.82 & Kalasin, KhonKaen, UdonThani \\
\hline 0418 & Lam Panchat Creek & 695.97 & 1.42 & Kalasin, SakonNakhon, UdonThani \\
\hline 0419 & Lower Pao Tributary & $4,216.24$ & 8.58 & $\begin{array}{l}\text { Kalasin, Mahasarakham, } \\
\text { SakonNakhon, UdonThani }\end{array}$ \\
\hline 0420 & Lam Nam Young Tributary & $4,134.31$ & 8.41 & $\begin{array}{l}\text { Kalasin, Roi-Et, Yasothorn, Mukdahan, } \\
\text { SakonNakhon }\end{array}$ \\
\hline 0421 & Lower Chi River Tributary & $2,762.90$ & 5.82 & $\begin{array}{l}\text { Yasothorn, } \quad \text { Roi-Et, } \\
\text { UbonRatchathani }\end{array}$ \\
\hline
\end{tabular}

Source: Water Crisis Prevention Center [13]

Effects through the Chi River Basin: The Chi River Basin has experienced rapid land-use changes, urbanization increases, and intensive and extensive agricultural land development. According to this 
view, overall land use in the Chi River Basin can be divided as presented in Table 2. In fact, the total area of agricultural land is about 3 million ha. Rice is the major crop, which covers approximately $40.7 \%$ of the agricultural land. Other crops include $18.8 \%$ of field crops, $0.4 \%$ of perennial plants, and $0.1 \%$ of fruit crops ${ }^{[19]}$ (Table 4).

Table 4:Summary of climate information

\begin{tabular}{lll}
\hline Climate variable & Mean annual value & Unit \\
\hline Temperature & 26.9 & ${ }^{\circ} \mathrm{C}$ \\
Humidity & 71.3 & $\%$ \\
Wind & 2.3 & knots \\
Cloudiness & 5.5 & Octa \\
Class-A pan evaporation** & 1,771 & $\mathrm{~mm} / \mathrm{year}$ \\
Potential evapotranspiration & 1,824 & $\mathrm{~mm} / \mathrm{year}$ \\
\hline
\end{tabular}

Source: Hydro and Agro Informatics Institute [20]

Rice growing in paddy fields is the main activity in the Chi River Basin, which is the poorest and least developed area in Thailand. Water shortages in some areas were severed and competed with the water use among communities, agricultural, and industrial sectors. Therefore, an integrated river basin management including public participation is necessary to solve drought problems ${ }^{[21]}$.

In the Chi River Basin, there are three main dams and reservoirs with a different primary purpose, namely, Ubon Rattana (Lam Nam Pong), Lam Pao (Lam Nam Pao), and Chulabhorn (Lam Nam Proam) Dams. Dams, weirs, and reservoirs have been constructed to induce gravity flow. In addition, dams and weirs are used water storage reservoirs and flood protection, which is the main cause of change in the hydrological regime of rivers. A lot of water is now diverted for irrigation and other purposes while water in reservoirs behind numerous dams provides substantial surface areas for evaporation lose.

Hydrology and Weather Beneficially of the Chi River Basin: The climate of the Chi River Basin is basically seasonal in nature conditions often result in floods and droughts. To depict the distribution and variation of climatic elements, all relevant climate information has been taken from the Thai Meteorological Department (TMD). Such information was obtained from 7 meteorological stations located inside the Chi River Basin and its vicinity.

The Chi River system is largely dependent on the monsoon rains. About $89 \%$ of the annual rainfall comes during the rainy season (May to October), while the rest $11 \%$ accounts for the dry period (November to April). The average annual temperature is $26.9^{\circ} \mathrm{C}$. The highest average the temperature in April is $35.9^{\circ} \mathrm{C}$ and the lowest average temperature in December measured $16.9^{\circ} \mathrm{C}$; monthly average ranges are from $23.1^{\circ} \mathrm{C}$ to $29.6^{\circ} \mathrm{C}$. The average relative humidity is $73.0 \%$, the relative maximum measured $94.9 \%$ and the mean relative humidity was $41.1 \%$; monthly, average ranges are 63.4-83.3\%. Average annual evaporation of 1,659.4 millimeters and the range of monthly averages is 113.4-174.3 mm; average cloudiness 4.9 OTT (0-10 OTT) range of monthly average 2.1-7.9 OTT; average wind speed is approximately 2.3 knots, with a monthly average range of 1.5-2.9 knots; and annual rainfall is $1,279.1 \mathrm{~mm}$ range of the monthly average $2.3-243.7 \mathrm{~mm} /$ year (Table 4 ) ${ }^{\text {[20] }}$ 
Step II: Integrated the Water Resource and Water Management: Water resources management must integrate the needs of all stakeholders. Community-based watershed management knowledge in natural resource management, water management in relation to community, watershed, and the available natural resources were all considered. The study area has always been subjected to problems prone to flooding. The situation has become more severe, resulting in flash floods from the upstream and stagnant floods in the downstream part.

Water resources within the $\mathrm{Chi}$ basin at present serves the following purposes: irrigation, hydroelectricity, flood control, water supply, and fisheries. Irrigation is the most important user for water, providing supplementary water in the wet season and virtually all available water in the dry season. In relation to water usage, the major water requirements include domestic consumption, agriculture, and industry ${ }^{[22]}$.The biggest water-consuming activity in the Chi River Basin is agriculture, with the largest consumption occurring in the dry season. The flat areas of the Chi River Basin haves very poor soils whose characteristics for rice growing improve when they become anaerobic after being flooded for long periods. The development of rice irrigation may not be economically profitable. However, the industry has resulted in retaining poor people in rural areas and not moving to large cities ${ }^{[23]}$ (Figure 10).
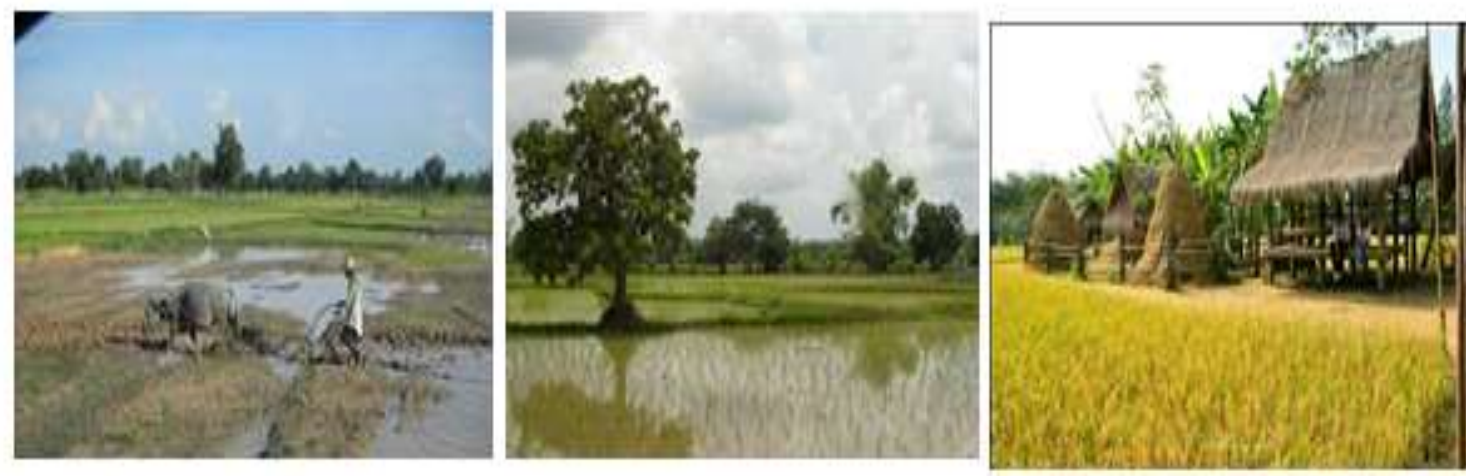

Source: Photos by research team

Fig. 10: Rice field processing product

Floods are considered as more damaging than beneficial, in the Chi River Basin. Heavy rainfall, which may cause floods near urban areas of Chaiyaphum, Khon Kaen, Maha Sarakham, and Roi-Et Provinces, is also a cause for concern in this area. Runoff increases in relation to increase in surface areas resulting in major flooding downstream ${ }^{[24]}$. Global warming has further impacted both severe draughts and flooding (The Royal Irrigation Department) ${ }^{[25]}$.

Step III: Lifestyle, Local Wisdom and Traditional Water Management of Rural Communities: Water user organizations can manage water resources from water sources costing with fairness and transparency, while water users are using water efficiently and sustainably allocated. The adoption of water resource rules and regulations should consider the lifestyle and the culture of each local community. Characteristics of lifestyle are the role that members of the community play, the responsibilities assigned, the structure and each community, and establishing. Water resources in a deliberate fashion will enhance the quality of life while conserving, protecting and restoring the natural resources (Figure 11). 

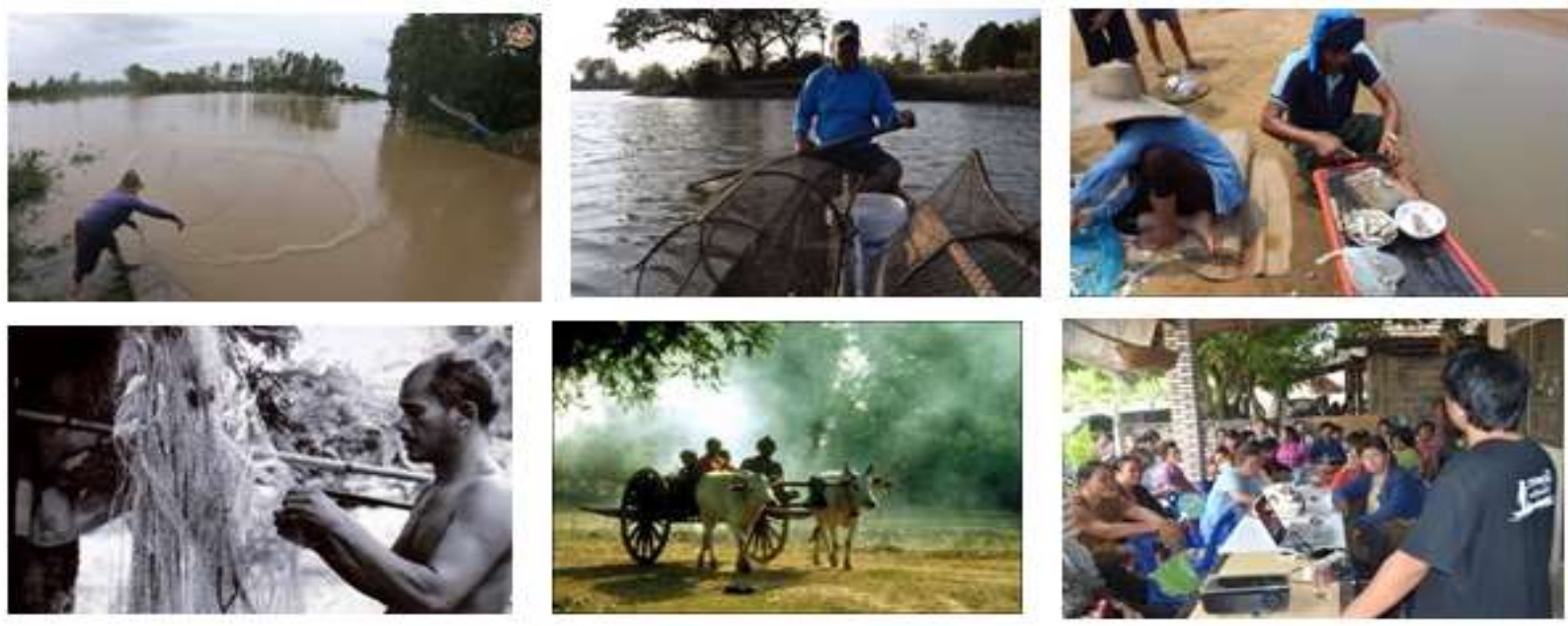

Source: Photos by research team

Figure 11: Lifestyle, local wisdom and traditional roles at the local communities whereas they are surrounding at the Chi River Basin

Conservation efforts that impact lifestyle are particularly important throughout households and communities. In the past, during the dry season, villagers went in a caravan with many carts to large rivers and stayed a few weeks to collect enough food. Fish were dried and preserved with salt and rice bran. This kind of fish is called "PLA RA". They would also prepare "PLA SOM" with salt and rice to make salty and sour fish. Nowadays such food is still a favorite for local household habitants. Water use is classified by whether it is an upstream or a withdrawal use and by whether it is a consumptive or non-consumptive use. Upstream uses include navigation, hydroelectric power, and fish and wildlife habitats, while withdrawal uses is the removal of water from the source ${ }^{[26]}$ (Figure 12).
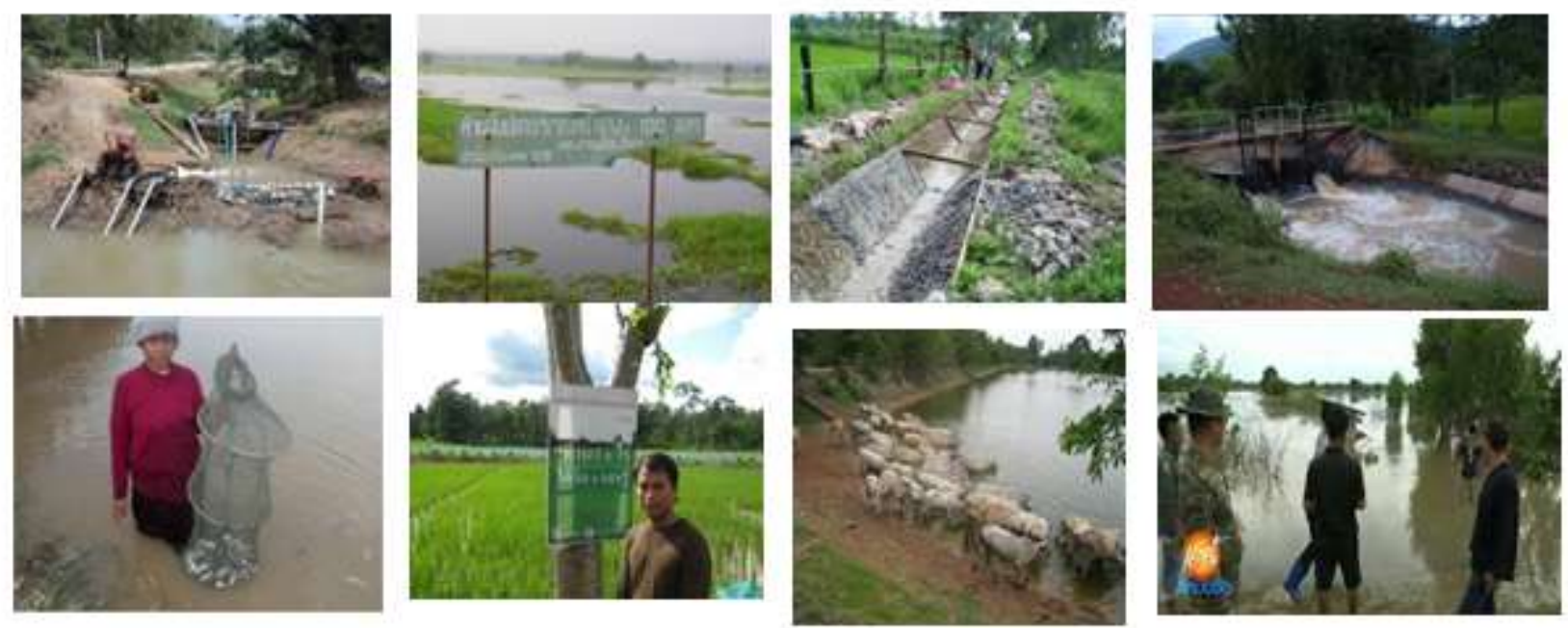

Source: Photos by research team

Fig. 12: Principles and priorities of water rights and water allocation by local wisdom and communities 
Step V: Research on the Integrated Participatory Action Research (IPAR) Method: Most importantly, after the competing interests are fully explored, actual solutions will be crucial ${ }^{[27]}$. The community-based organizations of interest are those from and representing underserved communities ${ }^{[28]}$. The present study was motivated by two main observations: residents' low involvement and a lack of systematic collaboration among stakeholders in various endeavors of community development. Interviews with residents revealed scattered networks, the bureaucracy of city administration, feelings of powerlessness, and frustration, as well as a lack of knowledge and citizen skills. This led to the examination of empowerment more closely. The development of water resource management regulations of water users' organizations that are based on local wisdom and the human environment was designed. The statistics involved, as previously addressed, and integrated all stakeholder interests with the Integrated Participatory Action Research (IPAR) method (Figure 13).
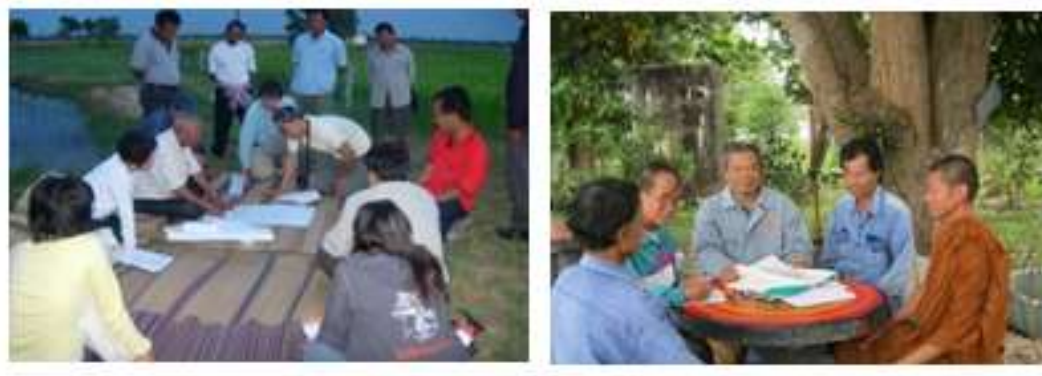

Source: Photos by research team

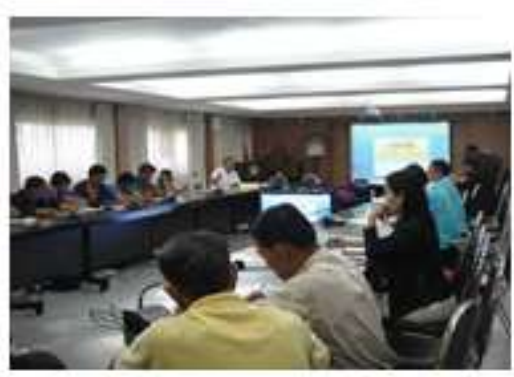

Fig. 13: Empirical data with the Integrated Participatory Action Research (IPAR) method

Population and Sample Target for the IPAR Research Method: Figure 13 as reported of this research study on effectuating the equitable development of rules and regulations on water management included the input of the following groups:

1. Irrigation Office 6, Khon Kaen, Royal Irrigation Department

2. Water Resources Office, Region 4, Khon Kaen, Department of Water Resources

3. Industrial Promotion Center Ministry of Industry

4. Khon Kaen Provincial Waterworks Authority

5. Research Committee, National Research Council

6. Special Water Law Specialist (Director, Pipat Kanjanapruk)

7. Integrated Northeastern Water Resource Research and Development Center, Faculty of Agriculture, Khon Kaen University

8. Chairmen /Vice-Chairmen and Head Directors of the Water User Organizations.

9. Water User Committee and Water Management Rules and Regulations

10.Water Reservoir Management Groups, such as Ban Non Moa Water Reservoir, Nang Dad Subdistrict, Nong Bua Dang District, Chaiyaphum; Hui Yai Reservoir, Ban Pa Wai Nung, Ban Phang District, Khon Kaen; Hui Aeng Reservoir, Ban Chok Cheik, Somdej District, Roi-Et; Hui Ka Kang Reservoir, Ban Loang Bom, Muang District, Maha Sarakham, etc.

11.Farmers Association of Irrigation Water Reservoirs in Khon Kaen and Poi-Et Provinces 
12.The Weirs' Water Users, such as; Lam Bong Weir, Ban Din Dam, PhuWieng District, Khon Kaen; Hui Wang Nong, Moei Wadee District, Roi-Et

13.Water User Cooperative Reservoirs, Na Nong Tum Sub-district User Cooperative Reservoir, Kang Kro District, Chaiyaphum, etc.

\section{National Research University Project of Khon Kaen University}

These agencies/institutions/persons provided valuable expert input for managing water resources both in the present and in the future. The Chi River Basin has always been subject to flooding, and it became increasingly severe over the past decade ${ }^{[29]}$. Drought is also one of the major hydrological hazards in this area. Periodically, severe droughts in this region caused crop losses, reservoir depletion, low flows, and water quality deterioration. According to the record of drought occurrence and impact collected by the Royal Irrigation Department, out of a total of 8,137 villages in the Chi River Basin, drought damage occurred in 4,808 villages $(59.1 \%)^{[25]}$. A number of organizations have carried out different activities for soil rehabilitation and conservation including growing votive grass to prevent erosion, promoting organic farming to build up soil organic matter, remediation of abandoned saline soil and soils with other problems, and revising of laws and regulations related to land use ${ }^{[21]}$

\section{RESULTS AND DISCUSSION}

The results were classified according to the research objectives, Part 1: Study and survey stakeholder and expert input from water users which include barriers and preventive solutions; Part 2: Establish rules and regulations for water management according to the competing interests of various water user sectors and particularly those in the watershed; Part 3: Address governmental enforcement of integrated rules and regulations on water management and barriers to enforcement; and Part 4: Develop coordinated and cooperative input which should be ongoing as rules are established on best practices on fair water management.

\section{Part 1: Study and survey stakeholder and expert input from water users which include a barrier and preventive solutions}

1. Consumer Water Consumption Organizations: Involve water users groups due to their role in supplying and producing tap water, water allocation, and distribution of water to consumers.

2. Industrial Water User Organizations: In the Chi River Basin, there are wide ranges of industrial activities composed of the textile industry, electronics industry, agricultural processing, ice-making, drinking water and beverages, building materials industry entrepreneurs.

3. Water User Organizations to Maintain Ecological Quality: Conservation and restoration specialists on the ecosystems of water resources and water quality in tributaries to ensure the integrity and balance of those resources is organized. The Khon Kaen Water Resources Office are one group and the public sector should establish a management organization for the conservation of aquatic ecosystems.

4. Water User Organizations: There is $73 \%$ of the land was used for agriculture, especially for rice cultivation and paddy fields. Most water users/groups use water from a pumping project and irrigation systems involve local government and support agencies. 
5. Irrigation Water User Organizations in the Chi River Basin: Water users in the Chi River Basin are encouraged to increase with participation in water management. Irrigation and water use maintenance is wise and effective, divided into two levels: basic water users which are Accounting126,085 members (households) and 1,342,682 rai is located in the irrigation and drainage area, and 2.83 million rai in thein the Chi River Basin.

6. Barriers to Implementation of the Groups: External factors in the water user organizations have been obstacles including outsiders who purchase land in the project area and violate member regulations results in water shortages. All stakeholders must be subject to the ongoing establishment of water management and allocation rules.

Part 2: Establish rules and regulations for water management according to the competing interests of various water user sectors

1. Characteristics of Traditional Water Management Rules and Regulations: Water user organizations have developed must represent all stakeholders and take into consideration the current state of the ecological, social, cultural, and community environment. The current rules for water management must reevaluate the appropriate allocation of resources.

2. Composition of Rules and Regulations: Water management is a science in the management of best practices and community rituals. Using a system of practices passed on from ancestors and local traditions need to be reevaluated with respect, to the conservation of natural resources and current knowledge and changes in use for impact on values, ecosystems, and biodiversity in the watershed to create a mechanism and to develop a community organization.

3. Regulation of Water Management Organizations for Consumption at the Community Level: The organization consists of 15 members, consisting of a chairman, vice-chairmen, treasurer, secretary, and secretary for 3 years and can work continuously if elected by the members, focusing on how to perform repairs, care and cleaning, maintenance costs, repair of buildings, system components from water user members and solicitation and participation of water users in system management.

4. Success in Operating an Irrigation System of an Organization: Factors that make the water user organization successful will be to understand the problems and solutions during the annual meeting and for the government to provide recognition and rewards to the successful organizations.

5. Weaknesses/Problems of Water Distribution and Distribution: Recognizing that the canal was used for many years, it is prone to collapse and rupture, and the drainage of the sink is too small for adequate discharge. Water user organizations must address barriers to water allocation, water supply, and water use.

6. Local Wisdom in Water Management: Issues of concern include reservoir, the width of tub, and water distribution system problems. Solutions may be to have a siphon system for the water distribution system from steel tubs into the agricultural area. State-owned enterprises provide technology that can become a complete water delivery system. New legislation and procedures should govern maintenance repair, buildings and canals, rice cultivation, water sharing, and cost-effective amounts of plants, pets, and overall community water usage. 
Part 3: Address governmental enforcement of integrated rules and regulations on water management and barriers to enforcement: There are currently many laws and regulations in Thailand that govern and regulate water resources. Some of them are obsolete with duplicate content. Water resources management should be centralized with common regulations and enforcement in accordance with the ecological culture.

1. Laws of Water Management: Developing rules and regulations that apply to water management in an effective and fair manner for all sectors while understanding that the current Laws that are based on past social and customary practices.

2. Laws related to Water Users Organizations: Water user organizations in areas where irrigation systems are provided for agricultural services should be integrated. There are five user groups: 1) the general water user group, 2) an administrative water user group, 3) the agricultural water user group, 4) the associational water user group, and 5) water user cooperative.

3. History of Thai Water Law: The first phase of the Rattanakosin Era 121 to 2007 was to oversee water maintenance for the canal. Laws included the Act of Navigating in Thai Waters, 1913, Royal Irrigation Act, 1985, Fisheries Act, 1947, National Park Act, 1961, and the Constitution of the Kingdom of Thailand BE 2550 (2007). These laws generally, allowed for the community to maintain and maintain natural resources and the environment.

4. The National Economic and Social Development Plans: No. 10 (2007-2011), No. 11 (20512-20516), and No. 12 (2017-2021) issued by Office of the National Economic and Social Development Board Office of the Prime Minister of Thailand lays out development agendas as well as flagship projects which need to be accomplished in order to prepare human capital, society and the economy for future challenges that are effective, beneficial, and sustainable for all.

5. Policies and Plans to Promote and Maintain National Environmental Quality (2007-2016): Environmental Quality Management Plan provides a framework for public review and participation in changing the management of natural resources.

6. Laws related to Water Resources Management: While there are many identified issues (22), the laws currently address the allocation of water for consumption. The next important issues are flood protection and prevention, the development, utilization, maintenance, and conservation of water resources. As a result, water resources management is not presently meeting the needs of water users fairly.

7. Water Resource: The quantity and quality of groundwater vary greatly depending on local hydrological conditions. Surface water, the total annual volume of water from rainfall in all river basins is approximately 800 billion $\mathrm{m}^{3}$, of which $75 \%$ or around 600 billion $\mathrm{m}^{3}$ is lost through the processes of evaporation and infiltration. The remaining $25 \%$ or 200 billion $\mathrm{m}^{3}$ flows directly as surface runoff into rivers and streams of the Chi River basins. Water resource management and development would best address the land and water resources, soil and water conservation, rain-fed and dry-land agriculture, land reclamation, control of shifting cultivation, vegetation cover, and their improvements. At present, there is no integration of resources and water resource management. 
Part 4: Develop coordinated and cooperative input which should be ongoing as rules are established on best practices on fairwater management: The research team conducted, collected, analyzed, and compiled relevantly secondary data from various sources. The goal was to recognize and understand the nature of the laws pertaining to water resources and maintenance of irrigation works, including water dams, flood gates and water users in the irrigation systems.

1. Fundamental Development of Water Management Regulations: There are a number of duplicate versions and inconsistencies between those proffered by governmental agencies, organizations and institutions.

2. The Synthesis and Development of an Effective and Fair regulation of traditional Water Management Regulations: Common definitions are needed when drafting the effective and fair rules of water resources and water resources management.

3. Draft Regulations are the Result of Studies: Once promulgated, they should be enacted and recorded with the Prime Minister's Office, the draft regulations of the Office of the Prime Minister shall be submitted by the relevant government agencies for consideration to the Cabinet meanwhile must be submitted to the Office of the Council of State. These regulations relate to the use of specific water bodies that are mandatory. The regulations enacted would maximize the benefits of water resources from all sectors, of course including agriculture that summary with Figure 14.
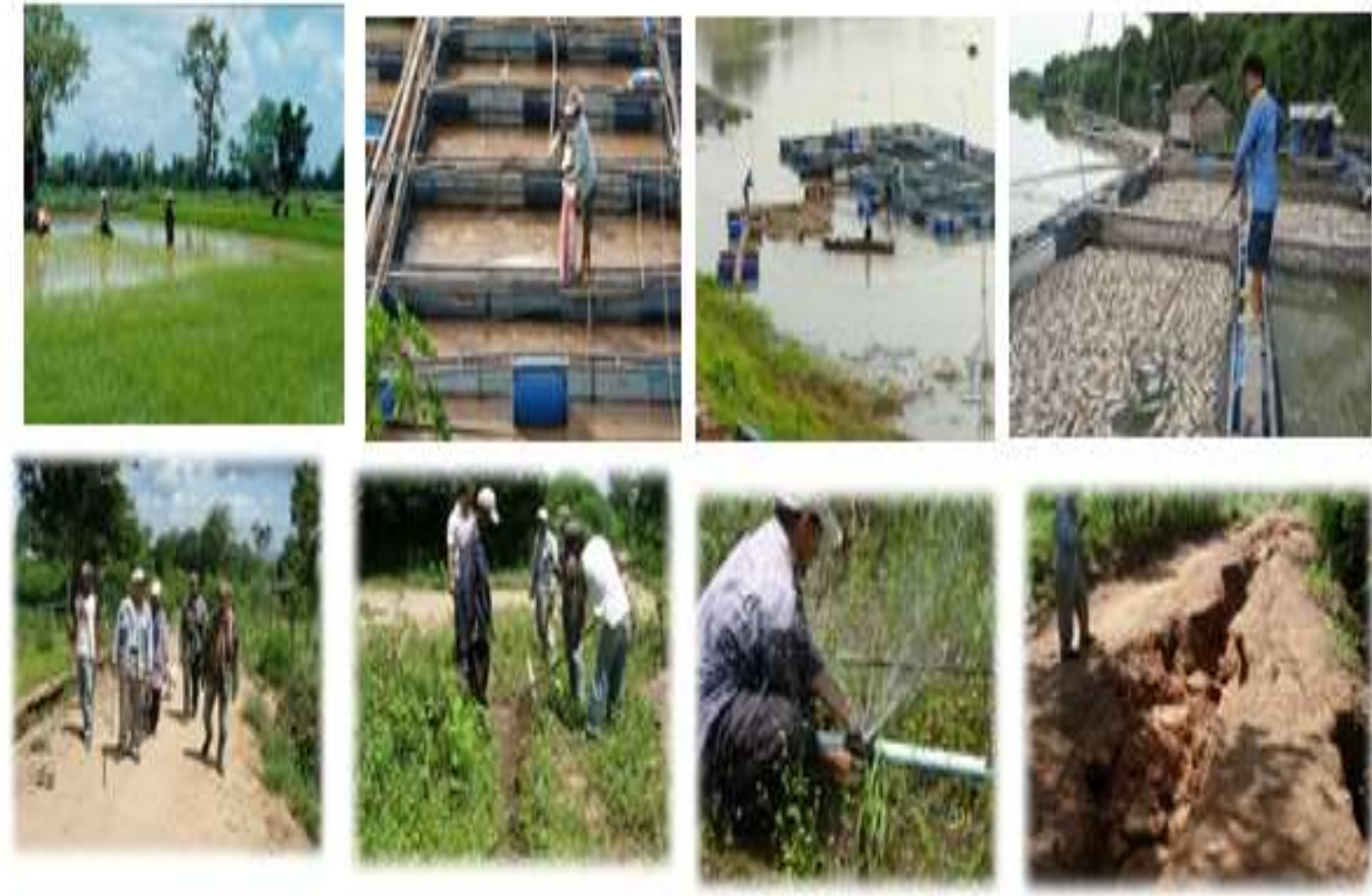

Source: Photos by Research Team (2013)

Fig. 14: Lifestyle, local wisdom, and traditional water management of rural communities for effectiveness and fairness, problems of users, and construction and repair of damaged parts. 


\section{CONCLUSIONS}

The aims of this research study were to engage all stakeholders from a variety of interested and affected groups, water user organizations, and institutions to provide initial input and integration into the setting up of regulations on water management; and then seek a centralized approach to adoption and enforcement by the government. The integrated approach which will continue through Integrated Participatory Action Research (IPAR) and Participatory Rural Appraisal (PRA) was designed to streamline efficient and fair water management regulations.

Consumer water consumption organization and maintain responsibility for maintenance and repairs, and water supply equipment must also be managed for buildings, water pipes, and water meters and fees. The industrial use of large quantities of water and agriculture uses are also significant issues. The integrated approach involves water sources and groundwater in the Chi River.

Water user organizations exist to maintain the ecological quality, conservation, and restoration of ecosystems and water resources of rivers, and streams. These groups protect fish farming and water for agriculture. Water Resources Bureau 6, Khon Kaen that controlling the natural water sources was $73 \%$, focused on agriculture. Also, groups exist for rice cultivation and general irrigation water management, water allocation, water distribution, repair, and maintenance.

Water user organizations in the Chi River Basin are encouraged to increase stakeholder participation and expertise in water management operations, the irrigation maintenance, and water utilization increased number of user groups on behalf of the various reservoirs, and households, classified by the province in the Chi River Basin, while. Irrigation areas are under the management of existing water user organizations.

To carry out the enactment and enforcement of rules and regulations of water management, agricultural cooperatives, and banks will be engaged as investments are needed for upgrades representatives of government agencies: The Royal Irrigation Department, Department of Cooperative Promotion of the Ministry of Agriculture and Cooperatives, Department of Water Resources Department of Ministry of Natural Resources and Environment, representative of Local Government Organization Groups; institutions and organizations on behalf of water users. These entities will continue to review, enhance and integrate rules and regulations that effectively and manage and allocate water resources.

\section{ACKNOWLEDGMENT}

This research was partially supported by The National Research University Project of Khon Kaen University. We thank our colleagues from the Irrigation Office 6, KhonKaen, Royal Irrigation Department; Water Resources Office, Region 4, KhonKaen, Department of Water Resources; Industrial Promotion Center Ministry of Industry; KhonKaen Provincial Waterworks Authority; Research Committee, National Research Council; Special Water Law Specialist (Director, Pipat Kanjanapruk); Integrated Northeastern Water Resource Research and Development Center, Faculty of Agriculture, Khon Kaen University; Chairmen /Vice Chairmen and Head Directors of the Water User Organizations; Water User Committee and Water Management Rules and Regulations; Water Reservoir Management Groups; Farmers Association of Irrigation Water Reservoirs; The Weirs' Water Users; and the Water User Cooperative Reservoirs who provided insight and expertise that greatly assisted the research, although they may not agree with all of the interpretations/conclusions of this paper. 
We would also like to show our gratitude to the Local pearls of Wisdom in Northeastern, Thailand for sharing their pearls of wisdom with us during the course of this research and we thank Prof. Dr. Toansakul Santiboon of Curtin University of Technology, Western Australia, "anonymous" reviewers for his so-called insights. We are also immensely grateful to Prof. Dr. Gregg Alexander Santiboon of the Central University of Technology, South Africa for his comments on an earlier version of the manuscript, although any errors are our own and should not tarnish the reputations of these esteemed persons

\section{REFERENCES}

1. Food and Agriculture Organization of the United State. (2011).Geography, climate and population of Thailand. http://www.fao.org/nr/water/aquastat/countries_regions/THA/

2. S. Apipattanavis, S. Ketpratoom, \& P. Kladkempetch, Water management in Thailand. Irrigation and Drainage, 2018, 67: 113-117 , DOI: 10.1002/ird.2207

3. The Department of Water Resource, Ministry of Environment, Thailand. Ecosystem-based flood and drought management in river basins. In Thongkao, S. 2016. Panorama: Solutions for A Healthy Planet. 22 November 2017. https://panorama.solutions/en/solution/ecosystembased-flood-and-drought-management-river-basins2017)

4. Department of Water Resources, Ministry of Natural Resources andEnvironment. (2016). Annual report 2016: Water resource situation in Thailand. http://www.dwr.go .th/en/menu lannual 2559eng.pdf

5. The World Bank, Thailand environment monitor integrated water resource management: A way forward, June 2011.

6. N.Majang, Calculated net evaporation from reservoirs in the Chi-Mun River Basin,Thailand,2005,. http://hydrology.usu.edu/giswr/archive05/natmarjang/termproject/

7. The Ministry of Natural Resources and Environment. Environment and natural resources. $2017 . \quad$ https://thailand.opendevelopmentmekong.net/topics/environment-and-naturalresources/

8. RakThammachat.com, New theory farming system in Thailand. 2017. https://www.raktamachat.org/permaculture-thailand-asia/info/rak-tamachat-permaculturemedia/permaculture-master-plan

9. OpenDevelopment Thailand, Environment and natural resources. December 19, 2017. https://thailand.opendevelopmentmekong.net/topics/environment-and-natural-resources/

10. The World Bank Document, Thailand environment monitor integrated water resources management: A way forward. 2011. http://documents.worldbank. org/curated/en/ 367151468303847751/pdf/633680ESW0P1080RM00June020110Final0.pdf

11. Office of Royal Development Projects Board (RDPB). The two riverside river development for the Chi river project: Due to the royal,2009, works. http://km.rdpb.go.th/ Project/ View/ $\underline{7621}$

12. Government of Thailand. Thailand: Water level in Chi River still high. 2010. https://reliefweb.int/report/thailand/thailand-water-level-chi-river-still-high 
13. Water Crisis Prevention Center, Department of Water Resource of Thailand. The Chi river basin. 2012. http://mekhala.dwr.go.th/knowledge-basin-chee.php

14. GuideUbon.com, Introduction to Ubon Ratchathani Province (Photos: Miss Thailand Universe 2015, Competition). 2015. https://www.guideubon.com/2.0/pr-ubon/2015/

15. C. Suttisa, Civil Society in the Chi River, Northeast Thailand (PDF). Massey University, New Zealand. Ph.D. Thesis, 2011: 1-17.

16. Electricity Generating Authority of Thailand, Dams of the Northern of Thailand. 2015. https://www.egat.co.th/en/information/power-plants-and-dams?view=article\&id=56

17. Department of National Park, Wildlife and Plant Conservation, Types of the utilizing lands in the national parks through the chi river,2010. basin.https://sites.google.com/ site/lumnachi/ sakyphaph -khxng-phunthi-karkestr

18. Encychopedia.com, River and stream: Water profile system. 2018. https://www.encyclopedia.com/science/encyclopedias-almanacs-transcripts-and-maps/riverand-stream\#D

19. C. Chainuvati \& W. Athipanan, Agriculture situation: Crop diversification in Thailand. Department of Agricultural Extension, Ministry of Agriculture and Cooperatives, Bangkok, Thailand, 2012.

20. Department of Hydro and Agro Informatics Institute, Ministry of Science and Technology. (2012). Data collection and analysis: Development of data warehousing system 25 watersheds and droughts: A case study in the Chi river basin, 2012. http://www.thaiwater.net/ web/attachments/25basins/04-chi.pdf

21. Office of Natural Resources and Environmental Policy and Planning, United Nations framework convention on climate change (COP 24),2015. http://www.onep. go.th/ topics $\underline{156842}$

22. S. Patsinghasanee, Current situation of water resources in Thailand. Office of the National Water andFlood Management Policy,2012,.http://www.jsce-int.org/system/files/9_ Thailand _Supapap_Version4.pdf

23. K. Kuntiyawichai, Interactions between land use and flood management in the chi river basin. Doctoral Thesis, submitted in fulfillment of the requirements of the Academic Board of Wageningen University andthe Academic Board of the UNESCO-IHE Institute for Water Education, the Netherlands,2012. http://edepot.wur.nl/210227

24. P. Rujivanarom and S. Loho, Chi River floods 'even worse than 2011'national. The Nation. October 21, 2017.http://www.nationmultimedia.com/detail/national/30329775

25. Royal Irrigation Department, Drought conditions and management strategies in Thailand, 2014. http: //www.droughtmanagement .info/literature/UNW-DPC NDMP Country Report _Thailand_2014.pdf

26. Environmental Encyclopedia. (2003).Water allocation,2003.https://www.encyclopedia. com/environment/encyclopedias-almanacs-transcripts-and-maps/water-allocation

27. Institute of Development Studies, British Academy, 2014, Participatory research methods. Retrieved from http://participatesdgs.org/methods/ 
28. A. Krishnaswamy, Participatory research: Strategies and tools. Practitioner: Newsletter of the National Network of Forest Practitioners, 2004, 22: 17-22.

29. T. Santiboon, Effects of global warming on climate change in UdonThani Province in the period in60 surrounding years (a.d.1951-2010). World Academy of Science, Engineering and TechnologyInternational.Journal of Environmental and Ecological Engineering2011,:5,11, 700-711.

\section{* Corresponding Author: Prasit Prakongsri}

National Research University Project of KhonKaen University,

Department of Agricultural Extension

Faculty of Agriculture, Khon Kaen University, Khon Kaen, Thailand

Date of publication on line 28.07.2020 